Tersedia online di: http://ejournal-balitbang.kkp.go.id/index.php/JP
e-mail:jurnalpari@gmail.com
JURNAL PARI
Volume 3 Nomor 1 Juli 2017
p-ISSN: 2502-0730
e-ISSN : 2549-0133

\title{
KONSERVASI PREVENTIF TERHADAP KOLEKSI DI PERPUSTAKAAN POLITEKNIK KELAUTAN DAN PERIKANAN SIDOARJO
}

\author{
Preventive Conservation Toward Collection At Sidoarjo Polytechnic Of Marine And Fisheries Library
}

\author{
MARDIAH \\ Politeknik Kelautan dan Perikanan Sidoarjo \\ Diterima tanggal : 20 April 2017 diterima setelah perbaikan : 29 Mei 2017 disetujui terbit : 30 Juni 2017
}

\begin{abstract}
ABSTRAK
Salah satu bagian penting dari kegiatan pelestarian bahan perpustakaan adalah konservasi preventif. Konservasi preventif merupakan tindakan yang bertujuan untuk mencegah kerusakan bahan perpustakaan yang disebabkan oleh lingkungan, biota, manusia, dan bencana. Konservasi preventif memungkinkan bahan perpustakaan menjadi lebih awet dan terawat sehingga menghemat biaya perbaikan dan juga pengadaan. Bahan pustaka yang awet dan terawat tentu indah dipandang dan juga tidak berdampak buruk bagi kesehatan. Upaya untuk melakukan konservasi preventif terhadap bahan pustaka didukung oleh berbagai hal, di antaranya adalah: gedung yang representative untuk perpustakaan, sarana prasarana pendukung, pengetahuan dan perilaku pustakawan/staf perpustakaan dan pengguna perpustakaan, serta yang tidak kalah penting adalah dana. Penelitian yang dilaksanakan di Perpustakaan Politeknik Kelautan dan Perikanan Sidoarjo ini menggunakan metode observasi dan wawancara. Teknik observasi yang digunakan adalah partisipasi lengkap (complete participation) yakni dalam melakukan pengumpulan data peneliti sudah terlibat sepenuhnya terhadap apa yang dilakukan sumber data. Sumber data primernya adalah staf perpustakaan. Dari hasil penelitian ini dapat disimpulkan bahwa konservasi preventif terhadap koleksi atau bahan perpustakaan di perpustakaan Politeknik Kelautan dan Perikanan Sidoarjo telah dilaksanakan namun belum optimal. Belum lengkapnya sarana pendukung serta beberapa cara penanganan yang salah terhadap bahan perpustakaan/koleksi yang menyebabkan belum optimalnya kegiatan konservasi preventif.
\end{abstract}

Kata Kunci : Konservasi preventif, Koleksi; bahan perpustakaan, preservasi; pelestarian bahan perpustakaan

\section{ABSTRACT}

One important part of the conservation of library materials is preventive conservation. Preventive conservation is an action aimed at preventing damage to library materials caused by the environment, biota, human, and disaster. Preventive conservation allows library materials to be more durable and maintained so as to save the cost of repairs and procurement. Durable and maintained library materials will be not only beautifully seen but also good for health. Attempts to perform preventive conservation of library materials are supported by several factors, among which are: representative building for the library, supporting infrastructure, knowledge and behavior of librarian / library staff and library users, and no less important is funding. The research conducted at Sidoarjo Polytechnic of Marine and Fisheries library uses observation and interview methods. Observation techniques used are complete participation that is in data collection, the researcher has engaged fully over what data sources committed. The primary data source is the library staff. From the result it can be concluded that the preventive conservation of library collection at Sidoarjo Polytechnic of Marine and Fisheries library has been implemented but not yet optimal. Incomplete facilities, and some incorrect ways of handling of library collection causes poor preventive conservation activities.

Keywords: preventive conservation, library collections, library materials, preservation, preservation of library materials

Korespondensi Penulis :

JI.Raya Buncitan KP 1, Sedati Sidoarjo

Email : diahkakajodho@gmail.com 


\section{PENDAHULUAN}

\section{Latar Belakang}

Koleksi atau biasa yang disebut juga dengan bahan perpustakaan merupakan salah satu unsur penting dalam sebuah perpustakaan, selain ruangan, gedung, peralatan, tenaga dan anggaran. Unsurunsur tesebut satu sama lain saling mendukung untuk terselenggaranya layanan perpustakaan yang baik.

Koleksi merupakan aset dari perpustakaan, oleh sebab itu koleksi perlu dilestarikan untuk mempertahankan kandungan informasi yang ada di dalamnya dan juga bentuk fisiknya agar tidak cepat mengalami kerusakan. Koleksi perpustakaan yang mahal, diusahakan agar awet, bisa dipakai lebih lama dan bisa menjangkau lebih banyak pembaca perpustakaan.

Melestarikan bahan perpustakaan merupakan tanggung jawab seluruh staf perpustakaan oleh karena itu sudah menjadi kewajiban bagi setiap staf untuk mengetahui segala hal yang berkaitan dengan pelestarian bahan perpustakaan. Kaitan dengan pelestarian bahan pustaka, Ana Soraya (2011:4), mengutip prinsip-prinsip konservasi dalam buku Introduction to Conservation terbitan Unesco tahun 1979, bahwa ada beberapa tingkatan dalam kegiatan konservasi, yaitu : (1) preservation of deterioration yaitu tindakan preventif untuk melindung bahan pustaka dengan mengendalikan kondisi lingkungan dan melindungi bahan pustaka dari kerusakan lainnya, termasuk cara penanganan; (2) preservation yaitu penangan yang berhubungan langsung dengan bahan pustaka; (3) consolidation yaitu memperkuat bahan yang sudah rapuh dengan member perekat (sizing) atau bahan penguat lainnya, (4) restoration, memperbaiki bahan pustaka yang rusak dengan jalan menambal, menyambung, memperbaiki jilidan, dan mengganti bagian yang hilang, agar bentuknya mendekati keadaan semula; (5) reproduction yaitu membuat salinan (foto copy) dari bahan-bahan asli termasuk bentu mikro dan foto reproduksi, replica, miniature, dan alih media ke media baru.

Tujuan pelestarian bahan perpustakan adalah, menyelamatkan nilai informasi dokumen, menyelamatkan fisik dokumen, mengatasi kendala kekurangan ruang, mempercepat perolehan informasi.

Berbagai unsur penting yang perlu diperhatikan dalam pelestarian bahan perpustakaan adalah manajemen, tenaga yang merawat bahan pustaka atau sumber daya manusia, laboratorium, dan dana. Salah satu bentuk kegiatan pelestarian bahan perpustakaan, yang merupakan langkah awal adalah konservasi preventif yaitu tindakan pencegahan kerusakan bahan perpustakaan yang disebabkan oleh lingkungan, biota, manusia dan bencana.

\section{Permasalahan}

Permasalahan yang akan diangkat dalam penelitian ini adalah adalah apakah pelaksanaan konservasi preventif terhadap koleksi telah dilaksanakan di Perpustakaan Politeknik Kelautan dan Perikanan Sidoarjo. Penulis membatasi masalah hanya pada pelaksanaan konservasi preventif agar penelitian dapat dilakukan dengan lebih mendalam.

\section{Tujuan Penelitian}

Tujuan Penelitian ini adalah :

1. Untuk mengetahui tindakan konservasi preventif terhadap koleksi perpustakaan.

2. Untuk mengetahui apakah pengelola Perpustakaan Politeknik Kelautan dan Perikanan Sidoarjo telah melakukan tindakan konservasi preventif terhadap koleksi perpustakaan.

\section{Manfaat Penelitian}

Manfaat Penelitian ini adalah :

1. Sebagai tambahan pengetahuan dan wawasan penulis dalam hal kegiatan pelestarian koleksi pustaka terutama konservasi preventif.

2. Sebagai masukan bagi staf perpustakaan Politeknik Kelautan dan Perikanan Sidoarjo dalam melaksanakan tindakan konservasi preventif terhadap koleksi perpustakaan.

3. Sebagai bahan masukan bagi unsur pimpinan yang lebih tinggi dalam pengambilan kebijakan mengenai pengadaan peralatan maupun pengembangan perpustakaan ke depan.

\section{TINJAUAN PUSTAKA}

\section{Pengertian}

\section{Konservasi Preventif}

Kata konservasi berasal dari bahasa Inggris conservationyang berarti perlindungan, pengawetan, kekekalan (John M. Echos dan Hassan Sadily 2002:140). Preventif berasal dari bahasa Inggris preventive yang berarti pencegahan (John M. 
Echos dan Hassan Sadily 2002:446). Kaitannya dengan perpustakaan, konservasi preventif dapat diartikan sebagai tindakan pencegahan dalam hal melindungi dan mengawetkan bahan perpustakaan dari kerusakan.

Ana Soraya memberi pengertian konservasi preventif adalah merupakan tindakan yang bertujuan untuk mencegah kerusakan bahan pustaka yang disebabkan oleh lingkungan, biota, manusia, dan bencana (2011:12).

Konservasi preventif mencakup segala bentuk tindakan yang tidak langsung bertujuan untuk memperpanjang umur suatu dokumen dengan cara menjaga, merawat, pengawasan secara berkala, dan pencegahan dari faktor kimia, biologi, dan fisika, yang dapat menyebabkan kerusakan pada bahan perpustakaan.

\section{Koleksi Perpustakaan}

Koleksi Perpustakaan adalah semua informasi dalam bentu karya tulis, karya cetak dan atau karya rekam dalam berbagai media yang mempunyai nilai pendidikan, yang dihimpun, diolah, dan dilayankan.(UU. No. 43 Tahun 2007)

Koleksi perpustakaan adalah seluruh bahan pustaka yang dimiliki atau dikumpulkan, diolah dan disimpan dengan sistem tertentu oleh suatu perpustakaan untuk disebarluaskan pada masyarakat guna memenuhi kebutuhan informasi (Opong Sumiati : 36).

Koleksi perpustatakaan menurut bahannya terdiri dari :

\section{a. Koleksi Tercetak :}

1. Buku (Monografi) yaitu terbitan yang mempunyai satu kesatuan yang utuh, dapat terdiri dari satu jilid atau lebih, contoh: buku, laporan penelitian, skripsi, tesis, dan disertasi

2. Buku (Monograf) merupakan terbitan paling umum yang terdapat dalam koleksi perpustakaan. Menurut batasan UNESCO, buku adalah terbitan dalam jumlah paling sedikit 48 halaman, tidak termasuk halaman judul dan kulit. Buku merupakan alat komunikasi untuk menyampaikan informasi berjangka panjang dan paling berpengaruh kepada perkembangan budaya manusia. Di dalam buku dihimpun hasil pemikiran dan perjalanan manusia yang apabila dipelihara dengan baik, dapat lebih lestari dibandingkan dengan bahan perpustakaan yang lain.
3. Terbitan berkala (serial) yaitu terbitan yang diterbitkan secara terus menerus dalam jangka waktu tertentu; seperti harian, mingguan, bulanan, contoh : Surat kabat, majalah, buletin, jurnal penelitian, dll.

4. Peta

5. Gambar

6. Brosur, Pamflet, booklet, dll

b. Koleksi Tidak tercetak

1. Rekaman gambar: Film, Vidio, CD, Mikroflm, Mikrofis

2. Rekaman Suara : Piringan hitam, kaset, CD

3. Rekaman data magnetic / digital : Disket, CD file, dan pangkalan data

4. Bahan Kartografi lainnya : Globe

\section{Unsur- Unsur Perawatan dan Pelestarian Koleksi Perpustakaan}

Berbagai unsur penting yang perlu diperhatikan dalam pelestarian bahan perpustakaan adalah: manajemen, tenaga yang merawat bahan pustaka atau sumber daya manusia, laboratorium, dan dana.

\section{TUJUAN DAN FUNGSI PELESTARIAN KOLEKSI PERPUSTAKAAN}

Tujuan dan fungsi pelestarian bahan pustaka menurut Martoajmodjo (1993:5-7) adalah sebagai berikut :

\section{Tujuan pelestarian bahan pustaka, meliputi:}

a. Menyelamatkan nilai informasi dokumen.

b. Menyelamatkan fisik dokumen.

c. Mengatasi kendala kekurangan ruang.

d. Mempercepat perolehan informasi. Misalnya dokumen yang tersimpan dalam CD (Compact

Disc) atau bentuk digital lainnya sangat mudah untuk diakses, baik dari jarak dekat maupun jarak jauh, sehingga pemakaian dokumen atau bahan pustaka menjadi lebih optimal.

\section{Fungsi pelestaian dan perawatan bahan pustaka, meliputi:}

a. Fungsi melindungi

Melindungi bahan pustaka dari beberapa faktor yang menyebabkan kerusakan.

b. Fungsi pengawetan

Upaya pengawetan terhadap bahan pustaka 
agar menjadi lebih awet, tidak cepat rusak dan dapat dimanfaatkan lebih lama lagi.

c. Fungsi kesehatan

Menjaga bahan pustaka agar tetap dalam kondisi bersih; bebas debu, jamur, hewan perusak dan berbagai penyakit, sehingga pembaca maupun pustakawan jadi tetap sehat.

d. Fungsi pendidikan

Memberikan pendidikan kepada para pengunjung perpustakaan bagaimana cara menggunakan bahan pustaka dengan baik.

e. Fungsi Kesabaran

Kegiatan perawatan dan pelestarian bahan pustaka membutuhkan tingkat kesabaran yang tinggi dan suatu ketelitian.

f. Fungsi sosial

Kegiatan ini sangat membutuhkan keterlibatan dari oran lain, seperti para pengunjung dan pustakawan.

g. Fungsi ekonomi

Dengan pelestarian dan perawatan yang baik dapat meminimalisasi atau menghemat biaya pengadaan bahan pustaka

h. Fungsi keindahan

Penyusunan bahan pustaka yang rapi dan indah tentunya membuat perpustakaan telihat indah dan nyaman, serta dapat menambah daya tarik pengunjung.

\section{Penyebab Kerusakan Bahan Pustaka}

Penyebab kerusakan merupakan hal penting untuk diketahiu sebelum kita memutuskan tindakan pelestarina yang akan dilakukan. Penyebab kerusakan bisa dikenali secara langsung maupun dengan melakukan penyelidikan mendalam. Penyebab kerusakan sera lansung dapa terlihat dengan mata, dan yang membutuhkan penyelidikan dapat dilakukan melalui uji laboratorium.

Sebagai pengelola perpustakaan wajib mengetahui penyebab kerusakan bahan pustaka, sehingga dapat melakukan tindakan pencegahan, sehingga bahan perpustakaan itu lebih awet. Ada tiga kelompok faktor penyebab kerusakan yang menjadi masalah dalam pelestarian bahan perpustakaan, yaitu :

\section{Karakteristik bahan perpustakaan itu sendiri}

Umumnya bahan perpustakaan mempunyai sifat kimia dan sifat fisik yang tidak stabil. Cepat atau lambatnya kerusakan bahan perpustakaan bervariasi, mulai dari kertas yang tahan beratusratus tahun sampai pada kertas yang rapuh hanya dalam waktu 10 tahun.

\section{Faktor lingkungan}

Faktor lingkungan sangat berpengaruh terhadap bahan pustaka. Tiap-tiap tipe bahan pustaka mempunyai daya tahan yang berbeda terhadap pengaruh lingkungan tergantung dari karakteristik dan struktur dari tiap-tiap komponen yang ada di dalamnya. Faktor lingkungan yang mempengaruhi kerusakan terhadap bahan pustaka adalah :

\section{a) Temperatur dan kelembaban udara}

Dalam udara biasanya temperature berbanding terbalik dengan kelembaban udara. Semakin tinggi temperature, maka semakin rendah kelembaban udaranya, begitupun sebaliknya. Sebenarnya kekuatan kertas tidak begitu berpengaruh oleh perubahan suhu asalkan tidak terlalu ekstrim. Fluktuasi yang sangat drastic akan besar pengaruhnya terhadap kerusakan kertas, karena kertas akan mengendor dan meregang secara bergantian. Jika hal ini terjadi berulang kali maka akan menyebabkan putusnya ikatan rantai kimia pada serat selulosa.

Temperatur yang tinggi akan menyebabkan kertas menjadi getas, dan kelembaban yang rendah, menyebabkan tinta yang larut dalam air akan menyebar, sehingga kertas pada buku akan saling menempel.

\section{b) Cahaya}

Seperti yang dikutip dalam Anna Soraya (2011:5), mengatakan bahwa cahaya adalah energi elektromagnetik yang berasal dari radiasi matahari atau dari lampu listrik. Cahaya juga mempunya dampak yang buruk bagi bahan pustaka. cahaya akan mempercepat oksidari dari molekul seluloasa sehingga rantai ikatan kimia pada molekul tersebut terputus. Cahaya mempunyai pengaruh mengelantang yang menyebabkan kertas menjadi pucat dan memudarkan tinta. Karena pengaruh cahaya lignin pada kertas akan beraksi dengan komponen lain sehingga kertas berubah menjadi kecoklatan.

Sinar yang tampak dalam cahaya dapat merusak bahan pustaka, akan tetapi sinar yang 
tidak tampak lebih reaktif dan lebih merusak. Radiasi ultraviolet menyebabkanreaksi fotokimia yang memutuskan rantai ikatan kimia pada serat selulosa.

\section{c) Pencemaran udara}

Pencemaran udara seperti gas sulfur dioksida dan gas nitrogen oksida yang berasal dari hasil pembakaran minyak bumi dari pabrik dan kenddaraan bermotor dapat merusak bahan pustaka.

\section{Faktor Biota}

Jamur, Serangga dan binatang pengerat dapat merusak bahan pustaka. Kondisi yang hangat dengan temperature antara $32-35^{\circ} \mathrm{C}$ dan kelembaban di atas \&\% $\mathrm{RH}$, gelap dan sedikit sirkulasi udara, memnyebabkan jamur akan tumbuh subur. Jamur akan melemahkan kertas dan menimbulkan noda permanen.

Serangga dan binatang pengerat memakan serat dna bahan organic lainnya pada bahan pustaka. Serangga yang bias menyerang bahan pustaka adalah kecoa, silverfish, book lice, book worm, dan rayap. Kerusakan yang ditimbulkannya biasanya tidak dapat dikembalikan seperti semula, karena ada bagian-bagian yang hilang dan berlubang. Binatang pengerat merusak bahan pustaka karena dimakan dan dipakai untuk membuat sarang. Binatang pengerat juga biasanya meninggalkan kotoran yang menyebabkan bahan pustaka menjadi kotor.

\section{Faktor Manusia}

Kelompok penyebab kerusakan yang ketiga adalah yang berasal dari manusia. Manusia memiliki andil yang besar terhadap kerusakan bahan pustaka. Keterlibatannya dapat terjadi secara langsung maupun secara tidak langsung. Keterlibatan secara langsung misalnya pencurian, pengrusakan, dan penanganan yang kurang hatihati. Keterlibatan secara tidak langsung misalnya memproduksi kertas dengan kualitas rendah, mutu jilidan yang rendah, tidak adanya penyuluhan kepada staf dan pengguna perpustakaan.

\section{Bencana Alam}

Bencana alam seperti kebanjiran, gempa bumi, kebakaran, dan kerusuhan merupakan faktor yang sulit dielakkan. Bencana alam dapat memusnahkan bahan pustaka dalam waktu singkat. Faktor bencana alam, dapat terjadi karena murni adanya bencana tapi bisa juga disebabkan oleh kelalaian manusia, seperti kebakaran. Salah satu cara untuk menghindari kerusakan karena faktor bencana alam dibutuhkan perencanaan jauh sebelum sebuah perpustakaan didirikan, misalnya pemilihan lokasi dan perencanaan gedung yang sesuai standar.

\section{Tindakan Pencegahan}

\section{Pengendalian Lingkungan}

\section{a) Mencegah kerusakan karena pengaruh} temperatur dan kelembabab udara

Temperatur dan kelembaban udara yang ideal bagi bahan perpustakaan adalah $20^{\circ}-24^{\circ} \mathrm{C}$ dan $60-80 \%$ RH (Anna Soraya 2011:13). Cara ideal untuk menjaga temperature udara adalah dengan memasang Air Conditioning (AC) 24 jam sehari selama 7 hari dalam seminggu. Jika AC dipasang hanya setengah hari saja, maka kelembaban akan berubah-ubah, kondisi seperti ini malah akan mempercepat kerusakan kertas.

Jika dalam suatu perpustakaan hanya mampu mengoperasikan AC pada jam kerja atau jam buka perpustakan, karena pertimbangan biaya, sebaiknya AC dinyalakan pada temperaturnya $26^{\circ}-28^{\circ} \mathrm{C}$ untuk mencegah terjadinya fluktuasi temperatur yang tinggi pada siang dan malam hari, dan temperatur tersebut cukup sejuk bagi manusia dan aman bagi bahan perpustakaan.

Untuk mengatur kelembaban udara dibutuhkan dehumidifier atau silicagel. Dehumidifier digunakan untuk menurunkan kelembaban udara (humidity) dalam ruangan tertutup, sedangkan silicagel untuk menurunkan kelembaban udara dalam lemari atau filling cabinet.

Idealnya perpustakaan memiliki alat untuk mengukur temperatur dan kelembaban udara. Alat tersebut adalah thermohygrometer (mengukur temperature dan kelembaban udara) atau psychrometer (mengukur kelembaban udara).

\section{b) Mencegah kerusakan karena pengaruh cahaya}

Ada dua macam cahaya yang digunakan untuk menerangi perpustakaan, yaitu cahaya matahari dan cahaya lampu listrik. Untuk menghindari kerusakan bahan perpustakaan dari pengaruh cahaya, perlu dilakukan beberapa hal sebagai berikut: 
a. Gunakan UV filter untuk melindungi ruangan dari sinar Ultra Violet.

b. Hindari bahan pustaka dari sinar matahari secara langsung, gunakan tirai / blinds atau memasang kaca riben pada jendela. Perencanaan gedung perpustakaan perlu mempertimbangkan faktor cahaya matahari.

c. Jangan memasang spotlight dalam jarak yang dekat dengan obyek.

\section{c) Mencegah kerusakan karena pencemar udara :}

Bahan pencemar udara seperti gas-gas pencemar, partikel debu dan logam yang merusak kertas dapat dikurangi dengan langkah-langkah sebagai berikut :

a. Ruangan menggunakan AC, karena dalam $A C$ terdapat filter untuk menyaring udara dan ruangan ber $A C$ selalu tertutup sehingga mengurangi debu.

b. Di dalam ruangan dipasang alat pembersih udara (air cleaner). Di dalam alat ini terdapt karbon aktif yang dapat menyerap gas pencemar dan terdapat filter untuk membersihkan udara dari debu.

c. Menyimpan buku dalam kotak pelindung.

\section{d) Mencegah kerusakan karena faktor Biota}

Tindakan preventif untuk mencegah tumbuh dan berkembangnya jamur dan serangga adalah:

a. Memeriksa bahan perpustakaan secara berkala.

b. Membersihkan tempat penyimpanan.

c. Menurunkan kelembaban udara

d. Tidak menata buku terlalu rapat pada rak, karena akan menghalangi sirkulasi udara.

e. Melakukan fumigasi terhadap buku-buku yang baru dibeli atau baru diterima pihak lain, sebelum disimpan bersama-sama dengan buku yang lainnya.

Pada rak diletakkan bahan-bahan yang berbau untuk mengusir serangga seperti kanfer, naftalen, paradichloro benzena atau PBC.

f. Pada rak yang tetutup diletakan silica gel untuk menyerap kelembaban, karena kelembaban tinngi menyebabkan tumbuhnya jamur.

e) Mencegah kerusakan karena bencana Alam Bencana alam merupakan suatu peristiwa yang tidak disangka-sangka sebelumnya. Bencana alam bisa saja terjadi kapan saja tanpa diduga dan akibat yang ditimbulkannya dapat menghancurkan bahan perpustakaan. Oleh karena itu diperlukan kesiagaan dalam menghadapi bencana. Jika berada di daerah rawan banjir, sebaiknya koleksi perpustakaan ditempatkan di lantai atas. Bahan perpustakaan yang kehujanan atau kebanjiran harus secepatnya dikeringkan dalam ruangan hangat. Koleksi ini tidak boleh dijemur di panas matahari.

\section{d) Mencegah Kerusakan yang disebabkan oleh faktor manusia}

Manuasia adalah yang membuat, mengolah / menangani, dan menggunakan bahan pustaka, oleh karenanya manusia memiliki andil yang besar terhadap keruskan bahan pustaka. Pengaruh manusia terhadap kerusakan bahan pustaka dapat bersifat langsung ataupun tidak langsung. Penyebab rusaknya bahan pustaka oleh mausia dan pencegahannya antara lain:

\section{Penyimpanan dan Penataan}

\section{a) Penyimpanan}

Tempat penyimpanan yang tidak memadai dan tidak memenuhi syarat dan tata cara penataan yang kurang baik akan menyebabkan kerusakan fisik dan kimia pada bahan perpustakaan. Hal yang perlu diperhatikan dalam penataan dan penyimpanan untuk mencegah terjadinya kerusakan adalah sebagai berikut:

Tempat penyimpanan harus terbuat dari bahan yang tidak membahayakan bahan perpustakaan, misalnya :

- Tempat untuk menggulung dan menyimpan mikrofilm harus terbuat dari bahan yang tidak mudah terbakar;

- Rak buku cukup lebar untuk menyangga buku tanpa ada bagian buku yang menonjol.

- Rak yang paling bawah sekurang-kurangnya harus berada $10 \mathrm{~cm}$ di atas lantai utnuk menjaga kemungkinan terkena air jika ada pipa air yang bocor.

- Rak buku harus diletakkan pada ruangan dengan ventilasi yang baik dan jaraknya cukup supaya dapat mengambil dan mengembalikan buku dengan leluasa.

- Penyangga buku harus cukup lebar dan kuat agar dapat menahan buku dengan tegak. 


\section{b) Penataan}

Tata cara penataan bahan perpustakaan di rak (shelving)

- Menata buku tidak boleh terlalu rapat agar sirkulasi udara berjalan lancar dan memudahkan dalam mengambil dan menyimpan bahan perpustakaan, sehingga tidak gampang sobek atau tertekuk.

- Menata buku pada rak juga harus dilakukan dengan hati-hati untuk mencegah kerusakan.

- Buku sebaiknya ditata berdiri, kecuali buku yang terlalu tinggi atau terlalu lebar.

- Buku tidak boleh ditata miring, karena akan menyebabkan cover buku melengkung

- Buku tidak boleh diletakkan dengan punggung di atas, karena teks buku akan terlepas dari covernya.

Kebersihan

Ruangan dan bahan perpustakaan harus dibersihkan secara teratur. Staf harus diberi informasi bagaimana cara membersihkan bahan perpustakaan yang benar, karena kadang-kadang staf tidak mengetahui cara membersihkan yang benar.

Monitor terhadap program pembersihan sama pentingnya dengan pembersihan itu sendiri. Pemeriksaan secara berkala pada koleksi dan fasilitas penyimpanan dapat mengetahui lebih awal kerusakna oleh serangga atau akibat kelembaban.

Kebersihan dari staf dan pengguna jasa perpustakaan juga sangat penting. Tangan dan tempat kerja harus bersih untuk menjaga agar buku tidak cepat dekil.

\section{Penanganan}

Berbagai penangganan atau perlakuan terhadap bahan perpustakaan lainnya yang berdampak pada kelestarian bahan perpustakaan antara lain ;

- Bahan perpustakaan harus dilindungi dari penyebab kerusakan dari luar seperti debu, air, makanan, minuman, panas langsung dan kerusakan fisik lainnya.

- Sudut halaman tidak boleh dilipat.

- Tidak boleh membasahi jari dengan ludah untuk membuka halaman buku.

- Tidak boleh menandai halaman buku baik dengan pensil, bolpoin, pena, maupun stabile

- Buku baru atau buku yang dijilid kembali harus dibuka secara hati-hati.
- Buku tidak boleh dibiarkan tertelungkup

- Tidak boleh menggunakan karet gelang untuk mengikat buku

- Tidak boleh menggunakan sellotape untuk menambal buku yang robek.

- Memindahkan buku harus dilakukan dengan hati-hati sesuai dengan prosedur yang benar. Memindahkan buku biasa dilakukan dengan tangan, kotak (boxes) atau lori (kareta). Bawalah bahan perpustakaan semampu kita, untuk bahan perpustakaan dalam jumlah besar harus dibawa dengan kareta. Kareta dorong harus didisain sedemikian rupa untuk memperkecil kemungkinan rusak. Membuka bungkusan bahan perpustakaan harus dilakukan hati-hati, jangan menggunakan alat yang tajam.

- Pada saaat melakukan reproduksi seperti reprografi, fotografi dan fotocopy harus dilakukan agar bahan perpustakaan tidak mudah rusak dan rapuh.

\section{Pencurian dan Vandalisme}

Yang tidak kalah pentingnya dari program pelestarian bahan perpustakaan adalah keamanan dari pencurian dan pengrusakan. Prosedur pengamanan dapar dilakukan dengan cara pengawasan dalam ruang baca, pemeriksaan tas, pemasangan RFID dan detektor pada pintu keluar.

Kebakaran

Hal-hal yang perlu diperhatikan untuk menghindari kebakaran diantaranya adalah :

a. Kabel listrik harus diperiksa secara berkala.

b. Bahan yang mudah terbakar harus dijauhkan dari bahan perpustakaan.

c. Alarm seperti smoke detector harus dipasang untuk mengetahui dengan cepat adanya kebakaran.

d. Alat pemadam api harus diletakkan di tempattempat yang mudah dijangkau.

e. Alat pemadam kebakaran harus berupa gas karbondioksida, bukan air.

\section{METODOLOGI PENELITIAN}

Penelitian ini adalah penelitian deskriptif kualitatif yaitu metode yang memberikan gambaran yang sebenarnya keadaan dan situasi yang ada dengan mengumpulkan data-data yang diperlukan kemudian dipaparkan sesuai pedoman penulisan. 


\section{Sumber Data}

Sumber data dari penelitian ini adalah sumber data primer yaitu staf perpustakaan, dan sumber data sekunder yaitu buku, sumber dari internet, dan dokumen yang berkaitan dengan penelitian ini.

\section{Teknik Pengumpulan Data}

Untuk mendapatkan data dalam penelitian ini, penulis menggunakan teknik observasi dan wawancara.

\section{Observasi}

Observasi yang digunakan dalam penelitian ini adalah metode observasi partisipasi lengkap (complet participation) yakni dalam melakukan pengumpulan data peneliti sudah terlibat sepenuhnya terhadap apa yang dilakukan sumber data (Sugiyono, 2012 : 227). Obyek observasi dalam penelitian ini adalah :

a) Space: ruang dalam aspek fisiknya, dalam hal ini ruang dan gedung perpustakan

b) Actor: orang terlibat dalam situasi, yakni pengelola perpustakaan dan pemustaka.

c) Activity: kegiatan yang dilakukan oleh staf perpustakaan

d) Object: benda-benda yang terdapat di perpustakaa, dalam hal ini sarana perpustakaan

e) Act: perbuatanatau tindakan-tindaka tertentu yang dilakukan oleh staf perpustakaan

f) Event: Rangkaian aktifitas yang dikerjkan oleh staf perpustakaan

g) Time: Urutan Kegiatan

h) Goal: Tujuan yang ingin dicapai

i) Feeling Emosi yang dirasakan atau diekspresikan

Wawancara

Selain observasi, teknik pengumpulan data yang digunakan adalah wawancara. Dalam penelitian ini penulis menggunakan wawancara tidak bersstruktur yakni peneliti tidak menggunakan pedoman wawancara yang telah tersusun secara sistimatis dan lengkap untuk pengumpulan datanya (Sugiyono, 2012 : 233). Pedoman wawancara yang digunakan hanya berupa garis-garis besar permasalahan yang akan ditanyakan.

\section{Analisis Data}

Penelitian ini menggunakan analisis data Model Miles and Huberman yakni analisis data kualitataif dilakukan secara interaktif dan berlangsung secara terus menerus sampai tuntas sehingga datanya sudah jenuh (Sugiyono, 2012 : 246). Aktifitas dalam analisis data Model Miles and Huberman adalah sebagai berikut :

\section{Data Reduction (Reduksi Data)}

Mereduksi data berarti merangkum, memilih hal-hal yang pokok, memfokuskan pada hal-hal yang penting, dicari tema dan polanya.

Data Display (Penyajian Data)

Penyajian data dilakukan dilakukan dalam bentuk uraian singkat, bagan, hubungan antar kategori, flowchart,dan sejenisnya. Yang digunaka dalam penelitian ini adalah teks yang bersifat naratif.

\section{Conclusion Drawing / verification}

Penarikan kesimpulan dan verifikasi. Keimpulan awal yang dikemukakan masih bersifat sementara, dan akan berubah bila tidak ditemukan bukti-bukti yang kuat dan mendukung pada tahap pengumpulan data berikutnya. Apabila kesimpulan yang dikemukakanpada tahap awal didukung oleh data yang valid dan konsisten, maka kesimpulan yang dikemukakan merupakan kesimpulan yang kredibel.

\section{HASIL DAN PEMBAHASAN}

\section{Koleksi Perpustakaan Politeknik Kelautan dan Perikanan Sidoarjo}

Sebelum membahas lebih jauh tentang tindakan konservasi preventif terhadap koleksi, berikut ini akan penulis paparkan jumlah dan jenis koleksi Perputakaan Politeknik Kelautan dan Perikanan Sidoarjo sampai dengan Desember 2015.

Tabel : Jenis dan Jumlah Koleksi Perpustakaan Politeknik Kelautan dan Perikanan Sidoarjo

\begin{tabular}{|c|c|c|c|}
\hline \multirow{2}{*}{ No. } & \multirow{2}{*}{$\begin{array}{c}\text { Jenis Bahan } \\
\text { Perpustakaan }\end{array}$} & \multicolumn{2}{|c|}{ Jumlah } \\
\cline { 3 - 4 } & Judul & Eksemplar \\
\hline 1 & Buku & 5,421 & 11,557 \\
\hline 2 & Majalah & 13 & 496 \\
\hline 3 & Buletin & 9 & 200 \\
\hline 4 & Jurnal & 12 & 337 \\
\hline
\end{tabular}




\begin{tabular}{|c|c|c|c|}
\hline \multirow{2}{*}{ No. } & \multirow{2}{*}{$\begin{array}{c}\text { Jenis Bahan } \\
\text { Perpustakaan }\end{array}$} & \multicolumn{2}{|c|}{ Jumlah } \\
\cline { 3 - 4 } & Judul & Eksemplar \\
\hline 5 & Laporan KIPA & 1018 & 1053 \\
\hline 6 & Tabloit & 2 & 15 \\
\hline 7 & Laporan & 25 & 42 \\
\hline 8 & Kliping & 0 & 221 \\
\hline 9 & Tesis & 18 & 18 \\
\hline 10 & Disertasi & 8 & 8 \\
\hline 11 & VCD/DVD & 32 & 201 \\
\hline 12 & CD KIPA & 623 & 623 \\
\hline 13 & Kartografi & 5 & 5 \\
\hline 14 & Prosiding & 1 & 1 \\
\hline 15 & Koran & 2 & 730 \\
\hline
\end{tabular}

\section{Gedung, Ruang, dan Sarana Perputakaan Politeknik Kelautan dan Perikanan Sidoarjo}

Gedung, ruang, dan sarana merupakan faktor pendukung kegiatan pelestarian bahan pustaka baiksecara langsung maupun tidak langsung.

\section{Gambaran Umum Gedung dan Ruang}

Perpustakan Politeknik Kelautan dan Perikanan Sidoarjo menempati gedung dengan luas $\pm 241,72 \mathrm{~m}^{2}$. Di dalam gedung tersebut terdiri dari beberapa ruang yaitu; ruang koleksi sekaligus ruang baca dan ruang referenensi yang hanya dibatasi sekat dengan luas $99 \mathrm{~m}^{2}$, ruang layanan sekaligus tempat penitipan dan ruang administrasi dengan luas $33 \mathrm{~m}^{2}$, ruang kanit sekaligus ruang pengolahan dengan luas $16.5 \mathrm{~m}^{2}$, laboratorium bahasa sekaligus ruang audio visual dengan luas $\pm 85.5 \mathrm{~m}^{2}$, dan toilet dengan luas $\pm 2.72 \mathrm{~m}^{2}$.

Letak gedung perpustakaan jauh dari jalan maupun dari pabrik yang dapat menimbuulkan pencemaran udara.

\section{Pencahayaan Gedung / Ruang}

Gedung / ruang Perpustakaan Politeknik Kelautan dan perikanan Sidoarjo umumnya menggunakan pencahayaan alami di siang hari, kecuali pada saat mendung atau hujan. Posisi jendela dalam ruang koleksi dan ruang baca mengahadap ke utara dan selatan, sehingga tidak ada cahaya matahari langsung yang mengenai bahan perpustakaan, yang dapat mengakibatkan kerusakan pada bahan perpustakaan. Di ruang baca dan koleksi tidak memiliki tirai atau gorden yang berfungsi untuk meminimalisir sinar matahari, karena memang tidak dibutuhkan.

Pencahayaan buatan dalam ruang koleksi dan baca menggunakan lampu neon 15 watt sebanyak 3 buah, seharusnya 4 buah, namun 1 buah mengalami kerusakan.

\section{Sirkulasi Udara dalam Gedung / Ruang}

Ruang koleksi /ruang baca memiliki 5 buah jendela yang dapat dibuka dan 5 buah yang tidak dapat dibuka (kaca mati) di sisi utara, dan 1 buah jendela yang dapat dibuka dan 4 buah jendela yang tidak dapat dibuka (kaca mati) di sisi selatan, serta memiliki 12 kisi-kisi di sisi uatara dan 12 kisikisi di sisi selatan.

Jendela-jendela tersebut jarang dibuka, kecuali pada saat-saat tertentu misalnya pada saat dibersihkan atau ketika AC mengalami gangguan. Kisi-kisi jendela ditutup dengan menggunakan plastik transparan agar kerja AC lebih optimal dan juga meminimalisir masuknya debu ke dalam ruangan.

\section{Keamanan Gedung / ruang}

\section{a) Keamanan dari Pencuri}

Pada jendela telah dipasang teralis, untuk mencegah pencurian dari luar. Gedung / belum dilengkapi dengan CCTV untuk memantau keamanan bahan perpustakaan dari perbuatan pengunjung / pengguna yang tidak bertanggung jawab.

\section{b) Keamanan dari Bencana}

Politeknik kelautan dan perikanan Sidoarjo berada di daerah yang rawan banjir. Beberapa bangunan di Politeknik Kelautan dan Perikanan Sidoarjo sering mengalami kebanjiran. Perpustakaan belum pernah mengalami kebanjiran, walaupun demikian segala kemungkinan bisa saja terjadi. Sebagai bahan perbandingan, bangunan sekitar gedung perpustakaan yakni rumah staf yang berada persis di samping perpustakaan sering mengalami kebanjiran. Perbedaan ketinggian gedung perpustakaan dengan rumah yang dimaksud tidak terlalu mencolok. Tinggi lantai (fondasi gedung) sebenarnya masih kurang. Sebagai gambararan Selisih tinggi lantai dalam ruang perpustakaan dengan teras sebesar $3 \mathrm{~cm}$, antara teras dengan halaman sebesar $2 \mathrm{~cm}$, antara halaman dengan jalan sebesar $\pm 5 \mathrm{~cm}$. 
Pada saat hujan yang disertai angin kencang, kadang terjadi kebocoran dari atap, terutama atap yang tepat berada di atas ruang koleksi / baca.

Gedung sudah dilengkapi dengan alat pemadam kebakaran, namun belum dilengkapi dengan alarm kebakaran. Instalasi listrik sudah dilakukan dengan baik.

\section{Sarana Pendukung Gedung / Ruang}

a. Terdapat 3 buah AC (Air Conditioning) di ruang koleksi sekaligus ruang baca yang terdiri dari 2 buah AC berkapasitas $1 \mathrm{PK}$, dan 1 buah AC berkapasitas 2 PK. AC berkapasitas 2 pk mengalami kerusakan, (sudah sering diperbaiki, namun kembali mengalami kerusakan). Total AC yang beroperasi di ruang koleksi / baca adalah 2 AC dengan kapasitas, masing-masing $1 \mathrm{pk}$.

b. Gedung / ruang perpustakaan belum memiliki alat pengatur kelembaban udara seperti dehumidifier

c. Gedung / ruang perpustakaan belum dilengkapi dengan CCTV

d. Gedung / ruang perpustakaan sudah dilengkapi dengan alat pemadam kebakaran, namun belum dilengkapi alarm kebakaran

\section{Tindakan Pencegahan (Konservasi Preventif)}

Pembahasan mengenai tindakan konservasi preventif terhadap koleksi buku di perpustakaan Perpustakaan Politeknik Kelautan dan Perikanan Sidoarjo dapat dijabarkan sebagai berikut :

\section{Pencegahan Kerusakan Karena Faktor Lingkungan}

\section{a) Mencegah kerusakan karena pengaruh temperature dan kelembaban \\ Di ruang koleksi / ruang baca Perpustakaan} Politeknik Kelautan dan Perikanan Sidoarjo telah terpasang AC. Penggunaan AC hanya pada saat jam buka untuk menghemat energy, idealnya $A C$ dihidupkan selama 24 jam. Penggunaan 2 buah AC yang masing-masing berkapasitas $1 \mathrm{PK}$ belum terasa optimal baik bagi kenyamanan pengguna maupun untuk keamanan bahan pustaka karena kapasitasnya tidak cukup mendinginkan ruang yang dipenuhi oleh pengunjung, walaupun suhu yang disetel adalah $16^{\circ} \mathrm{C}$.

Kebutuhan $\mathrm{AC}$ yang ideal untuk ruang baca I koleksi Perpustakaan Politeknik Kelautanan
Perikanan Sidoarjo bila menggunakan rumus rumus berikut adalah:

$(\mathrm{L} \times \mathrm{W} \times \mathrm{H} \times \mathrm{I} \times \mathrm{E}) / \mathbf{6 0}=$ kebutuhan BTU

(British Thermal Unit)

$(29,52 \times 36,08 \times 18 \times 12,136 \times 16) / 60=$

\subsection{3,985 BTU/h}

Kapasitas AC berdasarkan PK (

Paardekracht) :

$\mathrm{AC} 1 / 2 \mathrm{PK}= \pm 5.000 \mathrm{BTU} / \mathrm{h}$

$\mathrm{AC} 3 / 4 \mathrm{PK}= \pm 7.000 \mathrm{BTU} / \mathrm{h}$

$\mathrm{AC} 1 \mathrm{PK}= \pm 9.000 \mathrm{BTU} / \mathrm{h}$

$\mathrm{AC} 11 \frac{1}{2} \mathrm{PK}= \pm 12.000 \mathrm{BTU} / \mathrm{h}$

$\mathrm{AC} 2 \mathrm{PK}= \pm 18.000 \mathrm{BTU} / \mathrm{h}$

Jadi kurang lebih AC yang dibutuhkan adalah :

3 buah AC berkapasitas 2 PK dan 1 AC

berkapasitas $1 \mathrm{PK}$, atau

2 buah AC berkapasitas 2 PK dan 2 AC

berkapasitas $1 \frac{1}{2} \mathrm{PK}$, atau

$3 \mathrm{AC}$ berkapasitas $1 \mathrm{PK}$, dan $3 \mathrm{AC}$

berkapasitas $1 \frac{1}{2} \mathrm{PK}$

Keterangan :

$L=$ Panjang Ruang (dalam feet)

$W=$ Lebar Ruang (dalam fw eet)

$\mathrm{I}=$ Nilai 10 jika ruang berinsulasi (berada di lantai bawah, atau berhimpit dengan ruang lain). Nilai 18 jika ruang tidak berinsulasi (di lantai atas).

$\mathrm{H}=$ Tinggi Ruang (dalam feet)

$E=$ Nilai 16 jika dinding terpanjang menghadap utara;

Nilai 17 jika menghadap timur;

Nilai 18 jika menghadap selatan; dan

Nilai 20 jika menghadap barat ( bila jendela menghadap barat).

$1 \mathrm{M}=3,28$ Feet

Selain penyediaan AC yang belum ideal, Pepustakaan Politeknik Kelautan dan Perikanan Sidoarjo belum memiliki alat dehumidifier untuk mengatur kelemban udara dalam ruang. Untuk mengatur kelemban udara dalam tempat penyimpanan bahan perpustakaan yang tertutup sudah dilakukan dengan menaruh silica gel pada lemari buku yang tertutup dan lemari penyimpanan koleksi CD.

b) Mencegah kerusakan karena faktor cahaya.

Penempatan jendela pada gedung perpustakan sudah memenuhi syarat yakni, tidak ada cahaya matahari langsung, yang mengenai 
bahan pustaka. Penggunaan lampu neon juga tidak dari jarak yang dekat dengan bahan pustaka, namun cukup terang bila digunakan pada saat gelap misalnya saat mendung.

\section{c) Mencegah kerusakan karena faktor pencemaran udara}

Pencemaran udara dari polusi tidak terjadi di perpustakaan Politeknik Kelautan dan Perikanan Sidoarjo. Pencemaran udara yang ada adalah karena debu. Berbagai upaya untuk meminimalkan debu di ruang perpustakaan telah dilakukan, misalnya: menggunaan $A C$, yang tentu saja memiliki penyaring udara dan ruang selalu dalam keadaan tertutup; menganjurkan pengunjung untuk tidak memakai alas kaki ke dalam ruang koleksi / baca, tetapi meletakkan alas kaki ke tempat yang telah disediakan; membersihkan ruang secara berkala dengan menggunakan sapu, sulak, dan vacuum cleaner.

Sumber debu di perpustakaan Politeknik Kelautan dan Perikanan Sidoarjo, tidak hanya berasal dari luar ruangan, tetapi juga berasal dari tembok yang sering mengelupas. Hal ini menjadi salah satu penyebab masih adanya debu yang menempel di buku dan rak di beberapa titik. Perbaikan cet tembok sudah sering dilakukan, namun tidak bertahan lama, hal ini disebabkan karena tanah di mana tempat bangunan itu berdiri mengandung kadar garam (asin).

\section{d) Mencegah kerusakan karena faktor biota}

Mencegah kerusakan karena faktor biota seperti jamur, semut, rayap, kecoa, dan binatang pengerat lainnya telah dilakukan dengan berbagai cara misalnya : melakukan fumigasi setahun sekali, memberi kapur barus pada celah-celah buku di rak; mengolesi obat anti rayap di rak buku; tangan dalam keadaan bersih saat memegang / mengolah bahan pustaka; menghimbau pengunjung untuk tidak makan dan minum di ruang koleksi / baca.

\section{e) Mencegah kerusakan karena faktor bencana alam}

Mencegah kerusakan bahan pustaka dari kebanjiran dilakukan dengan tidak menempatkan bahan pustaka di lantai, menggunakan rak buku yang berkaki. Sedangkan usaha untuk menghindari kebocoran adalah dengan memperbaiki atap dan memindahkan rak buku dan meja baca dari area / titik yang rawan terjadi kebocoran.
Pencegahan Kerusakan Karena Faktor Manusia

\section{a) Pengguna Perpustakaan / Pemustaka}

Upaya untuk mensosialisasikan bagaimana menggunakan dan menangani bahan perpustakaan dengan benar sudah dilakukan oleh pustakawan pada pengguna terutama mahasiswa melalui pendidikan pemustaka dan juga pada staf perpustakaan lainnya. Namun upaya penyampaian I himbauan belum dilakuka secara kontinyu, sehingga belum membentuk suatu budaya atau kebiasaan.

Masih ditemukan beberapa bahan pustaka setelah dipinjam kemudian dikembalikan dalam keadaan sedikit kotor, dalam keadaan halaman yang terlipat, atau ada beberapa halaman yang terlepas. Ketidaktertiban pengunjung yang lain, yang kadang-kadang ditemukan adalah masih ada pengunjung yang makan jajan / snack secara sembunyi-sembunyi di ruang baca / koleksi.

\section{b) Pustakawan dan Staf Perpustakaan}

Pustakawan / staf perpustakaan mempunyai kewajiban dan tanggung jawab dalam melestarikan bahan pustaka. Andil pustakawan / staf perpustakaan dalam pelaksanaan konservasi preventif terhadap bahan pustaka dapat dilihat pada aktifitas berikut ini.

\section{Penataan dan Penyimpanan}

\section{Buku dan Bahan Cetak Lainnya}

Penataan buku di Perpustakaan Politeknik Kelautan Perikanan Sidoarjo belum semuanya sesuai standar penataan yang baik. Beberapa rak buku ditata sangat padat, hal ini disebabkan karena kurangnya jumlah rak, sedangkan jumlah bahan pustaka terutama bahan pustaka hasil cetak yang semakin banyak, sedangkan rak buku tidak bertambah. Tidak bertambahnya rak buku juga disebabkan karena keterbatasan ruang (space).

Penataan buku sudah dilakukan dengan benar yakni buku ditata berdiri, ditata tidak miring, dan ditata dalam keadaan punggung tidak menghadap ke bawah. Buku yang berukuran tinggi dan lebar, serta majalah, jurnal, dan sejenisnya ditata dalam posisi tidur.

Dalam menyimpan bahan pustaka yang belum diolah misalnya, belum menggunakan kotak penyimpanan secara khusus, tapi menggunakan kardus. Pada saat mengolah buku kadang-kadang buku diletakkan di lantai, hal ini menyebabkakan buku menjadi kotor dan lembab. 
Rak buku yang digunakan sudah sesuai standar, yakni cukup lebar untuk menjaga buku serta mempunyai kaki, untuk mengantisipasi kebanjiran atau merembesnya air dari celah ubin.

\section{Bahan Audio Visual (CD, VCD, DVD)}

Telah disiapkan lemari dan rak khusus untuk meletakkan bahan audio visual. Lemari / rak audio visual dibuat dalam bentuk tertutup untuk melindungi dari debu. Agar tidak berjamur, dalam lemari tersebut diletakkan silica gel.

\section{Bahan Kartografi (Peta dan Globe)}

Di perpustakaan politeknik kelautan dan Perikanan Sidoarjo belum memiliki rak khusus untuk menyimpan bahan kartografi seperti peta. Koleksi peta yang ada diletakkan di laci. Ukuran lacinya kecil, sehingga peta disiman dalam posisi dilipat, hal ini menyebabkan peta ada bekas lipatan yang menyebabkan peta mudah sobek.

\section{b. Penanganan}

Penanganan bahan perpustakaan yang dilakukan oleh pustakawan / staf perpustakaan ada yang sudah sesuai aturan, ada yang belum sesuai aturan. Penangan yang sudah sesuai aturan misalnya: Memindahkan buku yang berat dengan menggunakan troli; saat membuka halaman buku, tidak membasahi jari dengan air liur, membuka bungkusan buku dengan hati-hati, tidak meletakkan buku secara telungkup.

Beberapa penanganan yang belum sesuai aturan misalnya; masih ditemukan beberapa buku yang ditandai dengan pencil; pada saat diolah dan entri data buku, kadang buku langsung diletakkan di lantai; meletakkan makan dan minum di dekat bahan perpustakan; menambal buku yang sobek dengan menggunakan selotip.

\section{c. Kebersihan}

Berbagai upaya untuk menjaga kebersihan ruang perpustakaan telah dilakukan oleh pustakawan dan pengelola perpustakaan, misalnya

1. Menghimbau pengunjung untuk tidak makan dan minum di ruang perpustakaan.

2. Membersihkan ruang secara berkala. Menjaga kebersihan ruang dan bahan perpustakaan sudah dilakukan, namun terlihat belum optimal, karena masih ditemukan debu di ruang perpustakaan. Sumber debu di ruang baca / koleksi perpustakaan juga dari tembok yang mengelupas. Perlu dilakukan lebih intensif lagi dalam membersihkan ruang perpustakaan

3. Menghimbau pengunjung untuk menyimpan I meletakkan alas kaki di rak yang sudah disediakan di teras perpustakaan untuk meminimalisir debu dan kotoran yang masuk ke ruang perputakaan.

\section{d. Pencurian dan Vandalism}

Menjaga bahan perpustakaan dari pencurian belum dilakukan secara optimal, karena masih ditemukan bahan perpustakaan yang hilang dari rak. Kurangnya pengawasan dan tidak adanya fasilitas keamanan, seperti CCTV kadang menyebabkan beberapa bahan perpustakaan hilang. Kurangnya pengawasan di perpustakaan misalnya, kurang memantau aktivitas pengunjung di ruang baca / koleksi, kurang memperhatikan pengunjung yang meninggalkan ruang baca / koleksi atau keluar dari perpustakaan.

Di perpustakaan Politeknik Kelautan dan Perikanan Sidoarjo, tidak ditemukan perbuatan vandalism terhadap bahan pustaka seperti menyobek, menggunting, menyilet, maupun mencoret-coret buku. Adapun ditemukan buku yang sobek, disebabkan karena factor usia, salah penggunnaan atau penanganan.

\section{e. Kebakaran}

Mencegah kebakaran berkaitan erat dengan fasilitas keamanan gedung yg perlu disiapkan dan perilaku staf dan pengguna perpustakaan. Tidak ditemukan perilaku staf dan pengguna yang dapat menimbulkan kebakaran, misalnya merokok, meletakkan bahan yang mudah terbakar di dekat bahan perpustakaan, instalasi listrik dilakukan oleh tenaga professional serta diperiksa secara berkala.

\section{PENUTUP}

\section{Kesimpulan}

Berdasarkan hasil penelitian tentang konservasi preventif terhadap koleksi di Perpustakaan Politeknik Kelautan dan Perikanan Sidoarjo, penulis dapat menarik kesimpulan bahwa, Konservasi preventif terhadap koleksi Perpustakaan Politeknik Kelautan dan Perikanan Sidoarjo telah dilaksanakan, namun 
belum optimal, hal ini tergambar melalui :

a. Tata letak ruang dan gedung sudah memenuhi syarat melindungi bahan pustaka dari kerusakan, sedangkan prasarana gedung yang mendukung pelaksanaan konservasi preventif terhadap bahan pustaka belum memenuhi syarat bahkan belum tersedia.

b. Staf perpustakaan telah menjaga kebersihan dan menangani bahan pustaka dengan baik, walaupun masih ditemukan beberapa kasus kesalahan dalam penangan bahan pustaka.

c. Sudah dilakukan tindakan berupa fumigasi terhadap koleksi perpustakaan sebanyak satu kali dalam setahun.

d. Perilaku pemustaka / pengguna relative cukup baik dalam memperlakukan bahan pustaka, walau masih ditemukan beberapa kasus buku yang ditekuk atau halaman yang dilipat.

e. Sudah ada upaya untuk mesosialisakan tata cara menggunakan bahan pustaka yang baik terhadap pengguna, namun belum dilakukan secara kontinyu.

\section{Saran}

Berdasarkan kesimpulan di atas dapat ditarik beberapa saran baik bagi pengelola Perpustakaan Perpustakaan Politeknik Kelautan dan Perikanan Sidoarjo maupun bagi pengelola perpustakaan pada umumnya sebagai berikut :

a. Pustakawan wajib memberikan sosialisasi pada staf perpustakaan mengenai tata cara dan penanganan bahan pustaka yang benar secara terus menerus sehingga sehingga menjadi suatu kebiasaan atau budaya kerja yang baik.

b. Pustakawan wajib memberi sosialisai pada pengguna melaui pendidikan pemustaka tentang bagaimana memperlakukan bahan pustaka dengan baik.

c. Menyediakan sarana dan prasarana yang mendukung kelestarian bahan pustaka, seperti : dehumidifier, aircleaner, air conditioner, alarm kebakaran, rak / lemari penyimpanan bahan pustaka yang memenuhi standar, serta ruang / tempat khusus pelaksanaan fumigasi.

\section{Ucapan Terima Kasih}

Terima kasih penulis haturkan pada ;

a. Keluargaku tercinta yang telah memberikan motivasi dan merelakan waktu kebersamaanya demi menyelesaiakan tulisan ini.

b. Unsur pimpinan, baik Direktur Politeknik Kelautan dan Perikanan Sidoarjo serta Pembatu Direktur yang telah memberikan kesempatan dan motivasi dalam melaksanakan penelitian ini.

c. Rekan-rekan satu tim di Perpustakaan Politeknik Kelautan dan Perikanan Sidoarjo yang telah banyak membantu dalam penelitian ini, baik sebagai sumber data dalam penelitin ini, maupun dukungan dan motivasinya.

\section{DAFTAR PUSTAKA}

Ana soraya dan Lusia Damayanti. 2011. Pelestarian bahan perpustakaan : bahan ajar diklat calon pustakawan tingkat ahli. Perpustakaan Nasional RI. Jakarta

Echos, Jhon M. dan Hassan Sadely. 2002. Kamus Inggris Indonesia. Gramedia Pustaka Utama. Jakarta

Indonesia. 2009. Undang undang Republik Indonesia nomor 43 tahun 2007 tentang Perpustakaan. . Perpustakaan Nasional RI. Jakarta

Karmidi Martoatmojo. 1993. Pelestarian Bahan Pustaka. Depdikbud. Jakarta

Muhammad Razak. 1995. Petunjuk Teknis Pelestarian Bahan Pustaka. Perpustakaan Nasional RI. Jakarta

Najamudin. 2014, Cara Menghitung Daya dan kapasitas AC (Air Conditioning) Berdasarkan Volume Ruang Yang Akan Digunakan. www. academia.edu . [2 Desember 2016]

Nelwati dan Lily Suwarni. 2002. Pedoman Teknis Pengembangan Koleksi. Perpustakaan Nasional RI. Jakarta

Nurcahyono dan Nelwati. 2011. Pengembangan Koleksi : Bahan Ajar Diklat Calon Pustakawan Tingkat Ahli. Perpustakaan Nasional RI. Jakarta

Opong Sumiyati. 2011. Pengantar IImu Perpustakaan : bahan ajar diklat calon pustakawan tingkat ahli. Perpustakaan Nasional RI. Jakarta

Sugiyono. 2012. Metode Penelitiian Kuantitatif, Kualitatif, dan R\&D,Alfabeta. Bandung 